\title{
Immunotherapy for Breast Cancer Treatment
}

\author{
Miganoosh Simonian, Mozhan Haji Ghaffari and Babak Negahdari ${ }^{*}$ \\ Department of Medical Biotechnology, School of Advanced Technologies \\ in Medicine, Tehran University of Medical Sciences, Tehran, Iran
}

Received 27 July 2020; accepted 12 October 2020; published online 8 March 2021

\begin{abstract}
Breast cancer, as a heterogeneous disease, includes a wide range of pathological and clinical behaviors. Current treatment protocols, including radiotherapy, chemotherapy, and hormone replacement therapy, are mainly associated with poor response and high rate of recurrence. Therefore, more efforts are needed to develop alternative therapies for this type of cancer. Immunotherapy, as a novel strategy in cancer treatment, has a potential in treating breast cancer patients. Although breast cancer has long been considered problematic to treat with immunotherapy, as it is immunologically "cold," numerous newer preclinical and clinical reports now recommend that immunotherapy has the capability to treat breast cancer patients. In this review, we highlight the different immunotherapy strategies in breast cancer treatment. DOI: 10.52547/ibj.25.3.140
\end{abstract}

Keywords: Antibodies, Breast cancer, Immunotherapy

Corresponding Author: Babak Negahdari

Department of Medical Biotechnology, School of Advanced Technologies in Medicine, Tehran University of Medical Sciences, Tehran, Iran;

Tel.: (+98-912) 6571037; E-mail: negahdari_md@yahoo.com

\section{INTRODUCTION}

$\mathrm{T}$ hroughout the world, breast cancer is considered as one of the most prevalent cancer among women and the second most cancer worldwide ${ }^{[1]}$. Breast cancer is also more frequent in developed countries ${ }^{[2]}$, and annually, there is a $2 \%$ rise in its prevalence worldwide ${ }^{[3]}$. Such a rapid increase in the number of affected people has been reported from countries with the low incidence of breast cancer ${ }^{[4]}$. In the Middle East, this cancer is ranked in the first place. Similarly, in Iran, the incidence of breast cancer is estimated to be 23.1 per 100,000 women $^{[5]}$, and the available data indicates that the disease prevalence has elevated in the country so that since 1999 , it has stood in the first place among cancer cases in women nationwide ${ }^{[6]}$. In recent years, breast cancer is considered as a group of diseases, containing at least 21 distinct histological subtypes and four main molecular subtypes, which are constantly correlated with distinguishing clinical presentations and/or outcomes ${ }^{[7,8]}$. The most common type of invasive breast cancer (more than 75\%) is now histologically specified as "no special type," and called "ductal" carcinomas. Invasive lobular carcinoma is the most prevalent special histologic subtype accounts for about $15 \%$ of invasive breast cancers ${ }^{[9]}$. Table 1 summarizes the new classification of breast tumors reported by World Health Organization ${ }^{[10]}$. Breast cancer molecular subtypes are categorized through high-throughput microarray-based gene expression profiling. At the molecular level, there are four different molecular subtypes of breast cancer: luminal, normal breast-like, HER2, and basal-like. Luminal A (HR+/HER2-) is the most prevalent type of breast cancer that grows slower and tends to be less aggressive when compared with other subtypes. Luminal B (HR+/HER2+) is associated with poorer prognosis as it demonstrates a higher grade than luminal A (the higher proportion of breast cancer patients dropped to grade III and IV category in

List of Abbreviations:

ADC, antibody-drug conjugate; CAR, chimeric antigen receptor; CTLA-4, cytotoxic T lymphocyte-associated antigen 4; DCIS, ductal carcinoma in situ; EGF, epidermal growth factor; EGFR, epidermal growth factor receptor; EphA4, Ephrin A4; GPNMB, glycoprotein non-metastatic b; HER2, human epidermal growth factor receptor 2; HLA, human leukocyte antigen; HR, hormone receptor; MMAE, monomethyl auristatin E; PTK7, protein tyrosine kinase 7; TAA, tumor-associated antigens; TCR, T-cell receptor; TNBC, triplenegative breast cancers; TROP-2, trophoblast cell surface antigen; VEGF, endothelial growth factor 
Table 1. Histological typing of breast carcinomas ${ }^{[165]}$

Non-invasive lobular neoplasia

Lobular carcinoma in situ (classic, florid, and pleomorphic)

DCIS

DCIS of low nuclear grade

DCIS of intermediate nuclear grade

DCIS of high nuclear grade

Invasive breast carcinoma

Invasive breast carcinoma of no special type (including medullary pattern, invasive carcinoma with neuroendocrine differentiation, carcinoma with osteoclast-like stromal giant cells, pleomorphic pattern, choriocarcinomatous pattern, melanocytic pattern, oncocytic pattern, lipid-rich pattern, glycogen-rich clear cell pattern, and sebaceous pattern)

Microinvasive carcinoma

Invasive lobular carcinoma

Tubular carcinoma

Cribriform carcinoma

Mucinous carcinoma

Mucinous cystadenocarcinoma

Invasive micropapillary carcinoma

Carcinoma with apocrine differentiation

Metaplastic carcinoma (low-grade adenosquamous carcinoma, [high-grade adenosquamous carcinoma], fibromatosis-like metaplastic carcinoma, spindle cell carcinoma, squamous cell carcinoma, metaplastic carcinoma with heterologous mesenchymal [e.g. chondroid, osseous, rhabdomyoid, neuroglial) differentiation, and mixed metaplastic carcinomas)

Acinic cell carcinoma

Adenoid cystic carcinoma

Secretory carcinoma

Mucoepidermoid carcinoma

Polymorphous adenocarcinoma

Tall cell carcinoma with reversed polarity

Neuroendocrine neoplasms

Neuroendocrine tumor (grades 1 and 2)

Neuroendocrine carcinoma

Papillary neoplasms

Papillary ductal carcinoma in situ

Encapsulated papillary carcinoma

Solid papillary carcinoma (in situ and invasive)

Invasive papillary carcinoma

Epithelial-myoepithelial neoplasms

Malignant adenomyoepithelioma

Epithelial-myoepithelial carcinoma

Tumors of the male breast

In situ carcinoma

Invasive carcinoma 
luminal B) ${ }^{[11,12]}$. Basal-like (HR-/HER2-) cancers are known as triple negative since they are ER-, PR- and HER2-. The incidence rate of TNBC is very high in black women and those with a BRCAl gene mutation. The worst prognosis can be found in this group of cancers $^{[13]}$. In the last type of breast cancer, HER2enriched (HR-/HER2+) patients have the chance of targeted therapies. This novel immunotherapeutic strategy brings favorable outcomes for these patients ${ }^{[14,15]}$.

\section{Different mechanisms of immune evasion in breast tumors}

One of the major features of cancerous cell is its ability to escape and hide from adaptive immune responses $^{[16]}$. Diverse mechanisms such as defective activation of tumor-directed T-cells, imperfect T-cell penetration into the tumor milieu, or emergence of resistance to immune cells action can participate in tumor evasion process ${ }^{[17]}$. Genomic instability, an evolving hallmark of breast cancer, resulted in the production of tumor neoantigens. Although these neoantigens can easily be distinguished by immune system and eradicated through T-cell function and immunity against tumor ${ }^{[17,18]}$, cells can demonstrate rather different immunogenic behaviors, conditional to different subtypes of breast cancer ${ }^{[19]}$. In the particular profiling study, suspicious calcifications are related to hampered immune system activity as well as ERBB2 overexpression $^{[20]}$. Thus, breast calcifications could be beneficial to the management of patients with breast cancer for immunotherapy. Historically, these tumors are immunologically silent ${ }^{[17]}$ or "cold", which means the attendance of low neoantigen burden and negligible effector tumor-infiltrating lymphocytes. Due to an obstacle to T-cell-based immunotherapies when confronting with non-inflamed tumors, several studies have attempted to discover new approaches to expand immune cell infiltration to tumor microenvironment and subsequent improvement of patient's prognosis. Besides, direct tumor cell damage through the local tumor hyperthermia, serves as another valuable immunotherapy strategy for cancer, which has shown promising results in breast cancer patients ${ }^{[21-23]}$. Hyperthermia augments tumor cell sensitivity to antitumor immunological responses by boosting tumor surface HLA-I polypeptide-related sequence A expression. This specific sequence sensitizes tumor cell to natural killer cells and $\mathrm{CD}^{+}$cell-mediated lysis through the elevated levels of heat shock proteins and increasing exosomes release from tumor cells, respectively $^{[21]}$. Recognition of tumor cells is another key step toward a successful immune response. In this context, tumor immune escape can take place in high levels of estrogen. Excessive estrogen may attenuate IFN- $\gamma$ signaling and HLA-II expression, with apparent negative effect in all immune cells ${ }^{[24]}$. Moreover, estrogens enhance tumor cell survival and proliferation gene expression, along with growth factors (i.e. VEGF and $\mathrm{EGF}^{[25]}$ ). Since the presence of estrogen has beneficial effects on tumor development, antiestrogen therapies maybe a logical approach to improve the response to immunotherapeutic agents. On the other hand, estrogen deprivation initiates transcriptional events in favor of the tumor evasion and metastasis in patients receiving adjuvant hormonal therapy joints with HER2-targeted agents ${ }^{[26]}$. Therefore, blocking the PD-1/PD-L1 pathway in combination with hormone therapies should be applied with caution. Considering the reasons mentioned above, targeting growth factors by conventional mAbs has positive immunotherapy consequences by refining APCs activity ${ }^{[27,28]}$.

Resistance to mAb-based immunotherapies largely depends on possible pathways such as the activation of immuno-suppressive checkpoint pathways ${ }^{[29]}$. Although the blockade of the PD-1/PD-L1 pathway by FDA has been approved, atezolizumab appears to be among encouraging methods for immunotherapy. Indeed, it could achieve only 53\% response rate for metastatic breast cancer versus $33 \%$ for the placebo group $^{[30]}$. Similar to the PD-L1 pathway, PD-1 inhibitors have demonstrated the modest but promising results when administrated in breast cancer patients ${ }^{[17,19]}$. In this regard, PD-L1 status is considered the central point for anti-PD-1/PD-L1 therapies ${ }^{[31]}$; however, controversy remains regarding the prognostic value of PD-L1 expression ${ }^{[17]}$. Therefore, there is an urgent need to improve strategies for cancer immunotherapy as well as development and validation of novel biomarker panels.

Selection of apoptosis-resistant cells is another major hurdle, limiting immunotherapy success ${ }^{[16]}$. Since cellular apoptosis machinery can be activated by chemo- and immuno-therapies, tumor cell sensitivity to anticancer treatments can remarkably be influenced by the expression of anti-apoptotic factors ${ }^{[32]}$. Since different alternations in antiapoptotic proteins such as BCL-2, BMF ${ }^{[32]}$, and various pro-survival kinases ${ }^{[33]}$ were detected in patients with metastatic breast cancer, the justification of systematic classification techniques may be an inevitable approach in patients' selection, in order to find the subjects with better response to immunotherapy and combined treatments of protein inhibitors.

HLA-I surface expression has a great impact on success in T-cell-mediated immunotherapies. Thus, even small changes in the expression of HLA-I may confront breast cancer immunotherapy with a huge 
challenge $^{[16,34]}$. HLA-I expression was lost in $70 \%$ of the lymph node metastases, $37 \%$ of in situ breast carcinomas and $43 \%$ of the primary tumors ${ }^{[35]}$. Further studies are required to determine those breast cancer patients obtained more benefit from immunotherapies. Variable levels of HLA-I expression was detected in triple-negative breast tumors ${ }^{[36]}$. Alternation in HLA-I expression is involved in immunosuppressive mechanisms and induces immune escape of tumor. Also, HLA-II presentation pathway activation leads to the infiltration of lymphocytes into tumor and improved prognosis ${ }^{[37,38]}$. For these reasons, before immunotherapy, specific considerations related to these receptors should be taken into account. It is also worth emphasizing that HLA-I expression may increase due to targeting mitogen-activated protein kinase or HER $2^{[39,40]}$; hence, protein kinase inhibitors would be useful in the augmentation of T-cell-based immunotherapies.

\section{Rational for breast cancer immunotherapy}

Along with surgery as the main approach in the physical removal of the tumor, strategies such as radiation and chemotherapy can promote DNA damage or disrupt cell cycle, eventually leading to the death of cancer cells. No optimal chemotherapy regimen was identified for all subtypes of this heterogenous disease. Condensed chemotherapy appears to be more effective than conventional treatments; however, such chemotherapies require the growth factor usage, which substantially imposes additional costs to the patient. Additionally, the toxicity of chemotherapy impacts many organs. Vomiting, hair loss, chemotherapyinduced nausea, myeloid cell suppression, and neuropathy are the most frequent side effects ${ }^{[41]}$.

Hormone therapy, like chemotherapy and radiation therapy, is a common non-targeted treatment and often causes severe side effects ${ }^{[42]}$. Owing to the limitations of traditional therapies, researches have focused on developing targeted therapies, giving rise to sustainable responses. Targeted treatment represents a great hope in the fight against cancer. Immunotherapy has recently been considered as a powerful treatment that targets a specific protein. Targeted therapy imposes a minor impact on normal cells and subsequently, low adverse effects ${ }^{[43]}$. Immunotherapies provoke the body's immune system to diagnose and eliminate the malignant cells. Various strategies include (1) immunological checkpoint inhibition, (2) anti-tumor vaccines, (3) transmission of elective T-cell treatment, and (4) immunotherapy using mAbs (Fig. 1).

\section{Immunological checkpoint inhibition}

Breast tumors show a high level of PD-1, PD-L1 expression, CTLA-4, and indoleamine-2,3 dioxygenase, all of which can improve anti-tumor immunity as treatment targets ${ }^{[44]}$. CTLA-4 is an encouraging therapeutic way to boost anti-breast cancer immunity. Human mAb against CTLA-4, ipilimumab, was approved in 2011 for the metastatic melanoma treatment. There have currently been some clinical trials assessing the immunity and effectiveness of CTLA-4 block in the breast cancer. In phase 1 clinical trial, the therapeutic effects of ipilimumab combined with nivolumab, an anti-PD-1 mAb and a histone deacetylase inhibitor, was investigated in HER2-negative breast cancer patients (The National Clinical Trial number (NCT) 02453620). In a separate study, ipilimumab in combination with nivolumab was assessed in the treatment of the early stages of breast cancer (NCT 02833233). The immunity of another anti-CTLA-4 mAb, tremelimumab, was evaluated as a single treatment or with anti-PD-L1 (durvalumab) in advanced breast cancer treatment (NCT02527434 and NCT01975831). Although CTLA-4 block is an attractive approach for treating the breast cancer, its immunity-related toxicity is still a matter of concern. Because the CTLA-4 limits the T-cells colony expansion and activation, its blocking would reduce the required threshold for T-cell activation; consequently, it would often be accompanied by autoimmune intense side effects and immunity-related ones, such as colitis, dermatitis, and hypophysitis ${ }^{[45]}$.

PD-1 is a cell surface receptor that binds to PD-L1 (B7-H1) or PD-L2 (B7-DC) and inhibit T-cell function in non-lymphoid and lymphoid organs ${ }^{[46]}$. The PD-1 expression is easily detectable in tumor-infiltrating lymphocytes and linked to poor prognosis ${ }^{[47]}$. PD-L1 has been found to be overexpressed in breast cancer cells and accompanied by poor prognosis, namely, the advanced tumor grade and increased proliferation rate $^{[48,49]}$

PD-1 and PD-L1 are currently being applied for therapeutic purposes. Pembrolizumab, an anti PD-1 human $\mathrm{mAb}$, was tested in advanced TNBC patients (NCT01848834) $^{[50]}$. Expression of PD-L1 was detected in $60 \%$ of patients. The pembrolizumab effect was observed in 27 cases; the overall response was $18.5 \%$, and one patient was seen with a full response.

Atezolizumab is a human mAb that causes PD-L1 inhibition. It was examined with paclitaxel in 32 patients systematically treated for up to three years in the previous line ${ }^{[51]}$. Neutropenia was observed in $40 \%$ of cases, but no fatalities were reported; antitumor efficacy was found in $70 \%$ of TNBC patients. 


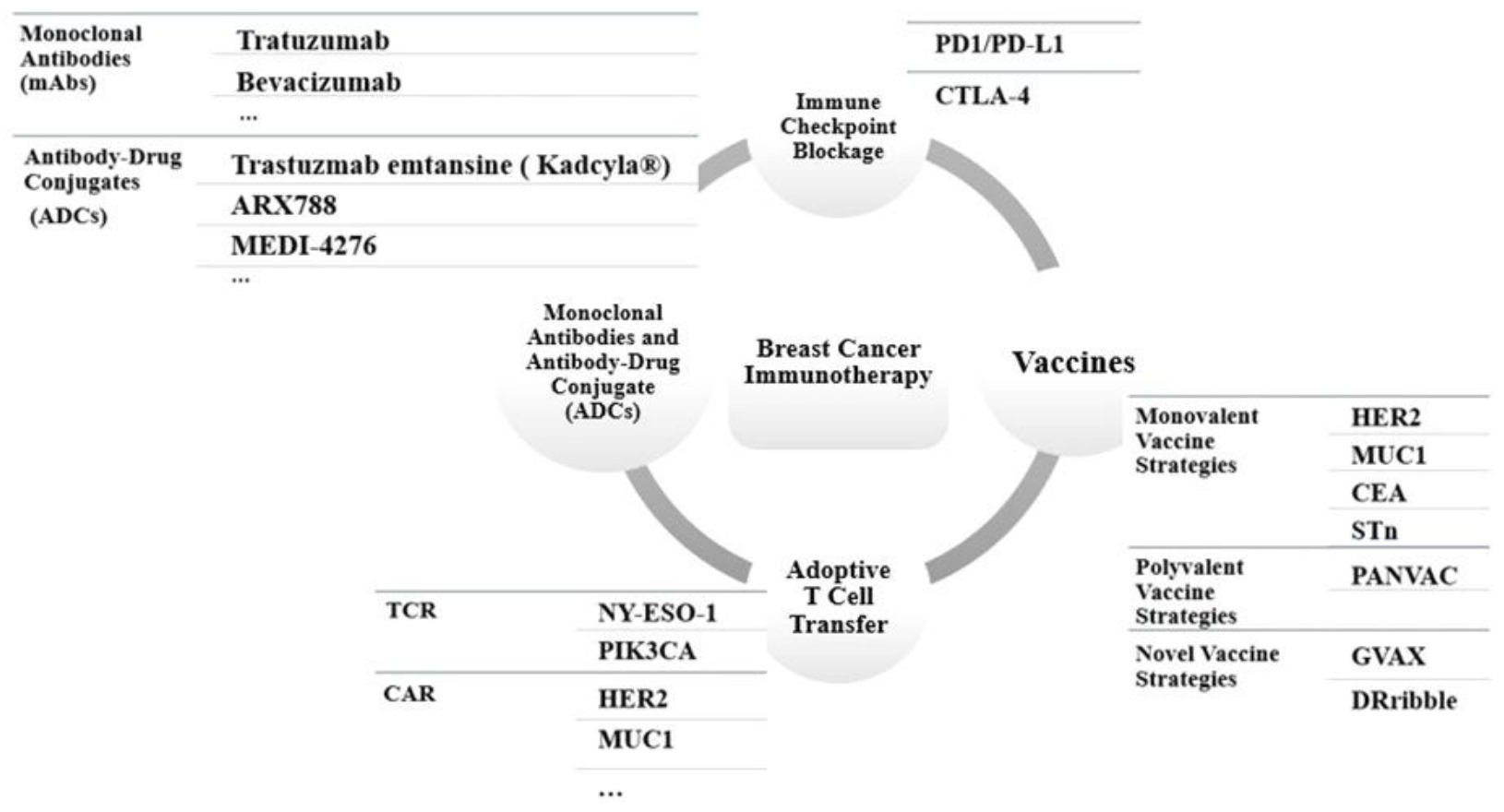

Fig. 1. Four different immunotherapy strategies in breast cancer.

Avelumab is another completely humanized antibody that has been evaluated in a clinical trial of phase 2 in breast cancer patients ${ }^{[52]}$. Its ineffectiveness was observed in 40 out of 168 patients $(23.8 \%)$. While these types of treatments have acceptable and promising results, it should not be neglected that in some cases, they can result in drastic side effects, e.g., death in several patients. Further studies are vital to assess the risk of this type of treatment. On the other hand, it seems that immunosuppressive mechanisms among various patients are different, which leads to exorbitant costs for each one. Moreover, this treatment could have adverse effects by systematic suppression of the immune system.

\section{Antitumor vaccines}

The aim of antitumor therapy vaccines is to attain an extremely specific antitumor cellular immune response. The effectiveness of antitumor vaccines is mainly rely on the stimulation of tumor-specific $\mathrm{T}$ lymphocytes to detect and eradicate the proliferated cancer cells ${ }^{[53]}$. In addition, early $\mathrm{T}$-cell responses could prevent tumor recurrence by inducing long-term immune memory ${ }^{[54]}$. Identifying mutated tumor antigens could assist the expansion of personal vaccination strategy. Several vaccine approaches, comprising of monovalent, polyvalent, and cellular vaccines, have been assessed. Monovalent vaccines were designed utilizing single TAA (such as HER2, sialyl-Tn, carcinoembryonic antigen, mucin 1, Wilms tumor gene, and telomerase reverse transcriptase) to stimulate an inherent antitumor response to aid cancer treatment ${ }^{[55]}$. Although appeared to be efficacious in targeting immune responses toward the specific antigen, monovalent vaccines may simplify the appearance of resistant tumor cells with decreased expression of tumor antigen ${ }^{[56]}$. To alleviate the negative outcomes of antigen loss, polyvalent vaccines have been developed. These vaccines use multiple TAAs to enable more drastic and varied antitumor responses. One example is PANVAC (pancreatic vaccine), a recombinant poxvirus-vector therapeutic vaccine that stimulates immune responses against the tumor antigens (carcinoembryonic antigen and MUC1). In phase 2 clinical study, more encouraging effects were detected in the vaccination group compared with the chemotherapy-alone group $(69 \% \text { vs. 53\% })^{[57]}$. However, polyvalent vaccines could carry multiple TAAs simultaneously. The third class of vaccines aims to improve the delivery of TAAs through the whole cell manufacture or cellular contents. GVAX, a granulocyte-macrophage colony-stimulating factor gene-transfected tumor vaccine ${ }^{[58]}$. A phase 2 study was performed with GVAX in combination with cyclophosphamide and trastuzumab in HER2-negative metastatic breast cancer (NCT00971737). Anti-tumor vaccines are recognized as an effective strategy for treating breast cancer and indicate spectacular features with acceptable toxicity profiles. However, there are limitations for these vaccines, namely, the imperfect 
antitumor immune response which is inadequate for tumor elimination ${ }^{[59,60]}$. The downsides of major histocompatibility complex in peptide vaccines are that each vaccine is used in a group of patients with expression of specific HLA molecules ${ }^{[61]}$. Systemically, injected peptides bind to nonprofessional APCs, which could lead to tolerance because of inefficient stimulation. In addition, the effectiveness of the vaccine is greatly affected by the very short half-life of peptides in the body ${ }^{[62]}$.

Overall, it is necessary to identify a set of antigens associated with tumor in each individual to optimize the production of stronger and more specific anticancer cells; for instance, vaccines. Targeting multiple antigens in these strategies is crucial not only to prevent the loss of the antigen due to selective pressure but also to enhance the chances of inducing immune memory that prevents metastasis and recurrence of the tumor. Eventually, although antitumor vaccines would bring immunity for breast cancer patients, their effectiveness is less than expected.

\section{Adoptive T-cell transfer therapy}

Transmission of selected $\mathrm{T}$ cells contains the extraction of patient $\mathrm{T}$ cells and also the genetic or chemical alteration to increase their activity, with the aim of creating antitumor immunity ${ }^{[63]}$. It has been observed that in a single tumor sample, there is a different population of lymphocytes with various antigenic characteristics and phenotypic populations $^{[64]}$. Extraction and manipulations to stimulate tumor-infiltrated lymphocytes did not indicate positive clinical effects in immunotherapy of breast $_{\text {cancer }}{ }^{[65]}$. Improvements in molecular biology and genetic engineering have resulted in the development of two new types of ACTs: (1) TCR gene transfer and (2) CAR gene transfer.

\section{TCR}

Gene transfer technology helps to develop new strategies in ACT category. Effector lymphocytes are made by the fusion of the patient's $\mathrm{T}$ cells with genes that encodes antigen receptors. These cells have the capability of eliminating tumor in vivo ${ }^{[66]}$. The T-cells redirection is achieved by expressing an antigenspecific TCR on cell surface, providing a recognition signal for $\mathrm{T}$ cells, followed by a co-stimulatory signal to regulate the $\mathrm{T}$ cells activation against tumors. TCRs may have better function to transform cancer therapeutics compared to tumor-infiltrating lymphocyte-strategies since they have enhanced tumor specificity and the possibility of clinically relevant doses of the production of these therapeutic cells. These approaches could generate more efficient $\mathrm{T}$ cells for targeting tumors without requirement for a new $\mathrm{T}$ cell activation overcoming the central and peripheral tolerance fundamental limitations ${ }^{[67]}$. A TCR may target either intracellular (it could add to the pool of potential targets) or extracellular antigen in the context of significant major histocompatibility complex presentation $^{[68]}$. A cancer testis antigen, NY-ESO-1, is expressed in $10 \%$ of TNBCs and has been revealed to be effectively targeted with TCR transfer immunotherapy ${ }^{[69]}$. Targeting PIK3CA, a common driver oncogene using genetically redirected $\mathrm{T}$ cells, eradicated target cancer cells ${ }^{[70]}$.

\section{CAR}

CAR T cells consists of an antibody-binding domain and a cell signaling domain. Elements that enhance Tcell persistence and activity are also included in CAR constructs $^{[71]}$. CARs specific for a broad range of antigens have been developed and effective treatment of breast cancer with these reported in several in vivo studies. Different CAR T-cells targeting, mucin 1, folate receptors and HER2 -MUC1 are available ${ }^{[72-74]}$. Adoptive cell therapy is a personal-centered therapy and the choice of different approaches and is strongly influenced by each patient's condition. Such treatments require complex preparations and procedures for each patient, long-term cell culture, experts, and patient preparation $^{[75]}$. Moreover, immune cells from cancer patients show different phenotypes when compared to healthy donors. One of the challenges in using patient's leukocytes is that the $T$ cells and dendritic cells obtained from cancer patients cannot function properly in many cases. Additionally, whether they can create a desired anti-tumor immunity or not is of concern ${ }^{[76]}$.

\section{Adoptive immunotherapy with mAbs and ADCs}

mAbs have been developed over the past two decades. Trastuzumab was the first $m A b$ targeting the extracellular HER2 cell domain, leading to the cessation of mitogen-activated protein kinase and PI3K/AKT intracellular signaling in the in vivo and in vitro environment. This antibody was finally received approval from FDA in $1998^{[77,78]}$. Unfortunately, only one-third of patients with HER2 amplification respond to this treatment ${ }^{[79]}$. Genetic changes, such as decreased expression or mutations in HER $2^{[80]}$, and the PIK3CA downstream mutation or PTEN loss of function, could affect the response to the anti-HER2 agent ${ }^{[81,82]}$. Bevacizumab was another mAb that could regulate angiogenesis and tumor survival against VEGF $^{[83]}$. However, angiogenesis inhibitors have not been successful in treating breast cancer. Failure to target angiogenesis is one of the most significant 
experiments in late 2000 clearly showing that angiogenesis is not a central mechanism for the disseminated tumor cells or micrometastatic disease.

Pertuzumab is a type of human monoclonal IgG antibody and has therapeutic confirmation in combination with trastuzumab for HER2-positive metastatic breast cancer patients ${ }^{[84]}$. Meanwhile, mAbs activate the immune response to kill cancer cells. For instance, opsonized epithelial tumor cells by trastuzumab could be killed through antibodydependent cytotoxicity via natural killer cell ${ }^{[85,86]}$. However, de novo mutations occur in $65 \%$ of patients, and $70 \%$ of the patients who initially respond to treatment eventually become resistant ${ }^{[87]}$.

The tyrosine kinase receptor family EGFR plays an important role in tumor formation. Evidence has shown that prescribing two inhibitors against EGFR or ErbB2 family works in perfect harmony and significantly increases antitumor activity. For instance, combination therapy with trastuzumab and lapatinib, an EGFR/ HER2 dual inhibitor, results in perfect cessation of BT474 breast cancer cells. These studies have also been extended to HER2-positive MCF7 breast cancer $\operatorname{model}^{[88]}$.

$\mathrm{PI} 3 \mathrm{~K} / \mathrm{AKT} / \mathrm{mTOR}$ is a key pathway in breast cancer. Everolimus and Palbociclib are proven anti-mTOR and anti-CDK4/6, respectively, which can be used to treat both ER-positive and HER2-negative breast cancer ${ }^{[89]}$. However, everolimus treatment can cause negative feedback to IRS-1/IRS-2, thus activating mTORC2 and AKT downstream signals ${ }^{[90]}$. Furthermore, the toxicity of the PI3K pathway inhibitor and the reduction of total survival are needed to be considered ${ }^{[91]}$. Regrettably, no targeted treatment other than standard chemotherapy for triple-negative breast cancer is recommended. This type of breast cancer is extremely invasive and requires continuous angiogenesis at all stages of tumor growth and expansion. Anti-vascular endothelial growth factor mAbs, bevacizumab, were confirmed by FDA; however, it was excluded due to its limited effect on the general survival of patients ${ }^{[92,93]}$. None of the anti-VEGF antibodies, ramucirumab, tyrosine kinase inhibitors, sunitinib, and sorafenib are effective in improving the survival of TNBC patient in phase 3 of clinical trial ${ }^{[94,95]}$. In addition, disappointing results from EGFR and cetuximab antibodies have been reported in clinical trials for TNBC ${ }^{[96,97]}$.

In the majority of cases, a specific mutation or a signaling pathway is targeted. Unfortunately these signal transmission pathway inhibitors are moderately efficient. Evidence has suggested a very low survival rate in several weeks or months, if metastatic condition is present, which is due to the significant limitations of current targeted therapies ${ }^{[98]}$. Reasons for internal resistance to targeted drugs include temporary antitumor activity, lack of attention to heterogeneity among patients, and heterogeneity in the tumor itself, as well as the lack of comprehensive insights into how cancer genomes and molecular networks regulate gene expression $^{[98,99]}$. Moreover, large molecules such as mAbs have a poor distribution due to their high molecular weight, which this could be an explanation for the difficult treatment of large solid cancerous tumors by $\mathrm{mAbs}^{[100]}$. To overcome these challenges, targeted therapies have emerged in the form of antibody-drug conjugates. Cytotoxic drugs are supposed to bind to antibodies via chemical linkers. The carrier antibody could detect cancerous antigen cells and deliver the conjugated drug to those cells ${ }^{[101,102]}$. ADCs are assumed perfect delivery systems for cytotoxic antitumor drugs ${ }^{[103]}$. Key factors for ADC development include the selection of the target antigen and the features of linker between the antibody complex and the drug. Other important factors are comprised of drug to antibody ratio and the effects of drug conjugation on antibody function. The first FDA approved ADC was in 2001 for acute myeloid leukemia patients. Gemtuzumab ozogamicin with the brand name of Mylotarg® was removed from the market in June 2010. In 2017, the product was reintroduced to the US market ${ }^{[104]}$. The second and third ADCs offered to the commercial market were Brentuximab vedotin with the brand name of Adcetris ${ }^{\circledR}$ and Trastuzumab emtansine with the brand name of Kadcyla. Brentuximab vedotin was approved for patients with Hodgkin's lymphoma on August 19, $2011^{[105]}$, while Trastuzumab emtansine was affirmed for metastatic breast cancer patients in February $2013^{[106]}$. The newest ADC, Inotuzumab ozogamicin, with the trade name of Besponsa ${ }^{\circledR}$, entered the market by European Commission for the treatment of adults with lung, acute lymphoblastic leukemia. Inotuzumab ozogamicin was later confirmed on August 17, 2017, for treating adults with lung, acute lymphoblastic leukemia or resistance to acute lymphoblastic leukemia $^{[107]}$. As breast cancer will remain a global public health problem for women in the future ${ }^{[2]}$, ADC could expand new methods and techniques in efficient treatments of breast cancer. Among 15 ADCs currently being evaluated for breast cancer, seven cases target the HER2. The HER2 recipient is one of the four receptors from the EGFR family and a protein receptor consisting of one extracellular domain and one intracellular domain. ADCs can be exceptionally effective in breast cancer with HER2 expression ${ }^{[108]}$. HER2 expression in tumor differs from normal tissue and increases in $20-25 \%$ breast cancer cases ${ }^{[109]}$. To date, Kadcyla ${ }^{\circledR}$ is the only ADC approved for HER2- 
positive metastatic breast cancer that has previously been treated with trastuzumab and taxane. T-DMI is composed of trastuzumab (humanized IgG1), conjugated with DM1, via an SMCC linker. T-DM1 has an average drug-antibody ratio of $3.5^{[110,111]}$. In these studies, T-DMI, an active drug with high tolerability, has shown a strong antigen activity in laboratory conditions, indicating an acceptable pharmacokinetic profile in xenograft samples of human tumor $^{[111]}$. T-DMI active catabolite (Lys-SMCC-DM1) demonstrates strong activity after antigen-dependent entry and antibody lysosomal degradation. However, Lys-SMCC-DM1 has poor membrane permeability, explaining why it has the least bystander properties. In addition, $50 \%$ of metastatic breast cancer patients do not reply to this treatment ${ }^{[112]}$. Similarly, there are significant demands for the presentation of newer conjugates for HER2-positive tumors and other types of breast cancer.

There are six HER2-based ADCs in clinical trials aimed to improve the activity and maintain or enhance the T-DM1 immunity. Moreover, the utilization of the following cytotoxic drugs with different actions has been assessed: DS-8201a for the transmission of exatecan, a topoisomerase inhibitor ${ }^{[113-116]}$, and SYD985 $^{[117,118]}$, a DNA-alkylating drug ${ }^{[119,120]}$, as well as ADCT-502 for the transmission of pyrrolobenzodiazepine that enters DNA minor grooves $^{[121]}$.

\section{ARX788 \\ ARX788 is an ADC with site specifically conjugated drug, an inseparable linker, and a combination of a linker and a cytotoxic drug that has amberstatin. Amberstatin (AS269) contains monomethyl auristatin $\mathrm{F}$ linked to a short polyethylene glycol spacer ${ }^{[122]}$. Preclinical ARX788 studies have shown activity in different xenograft models, such as ovarian and trastuzumab-resistant breast cancer.}

\section{MEDI-4276}

Targeting HER 2 can be carried out by both targeting different epitopes in HER2, as well as utilizing other cytotoxic drugs ${ }^{[123,124]}$. MEDI-4276 is completely a human IgG connected to a different epitope of HER2. This ADC is in the phase 1 of clinical trial in breast and gastric cancer patients.

\section{XMT-1522}

XMT-1522 uses a polystyrene-based polymer (Fleximer®) that significantly increases the loading of the cytotoxic drug on the antibody (DAR 12-15) ${ }^{[125]}$. The used mAb, XMT-1519, is attached to HER2 epitope different from those targeted by trastuzumab
The drug used in XMT-1519 is a new auristatin having a unique medicinal property.

\section{DS8201-a}

DS8201 is an anti-HER2 human mAb conjugated with topoisomerase I inhibitor, DXd. This ADC shows a cell-related HER2 toxicity effect in laboratory conditions in pancreatic, breast, and gastric cancer cells. Human model studies have also indicated HER2specific activity in tumors with heterogeneous expression of HER $2^{[114,115]}$. This ADC has entered in phase 1 of clinical trial. SYD985 contains conjugated trastuzumab connected to duocarmycin through maleimide coupling to inter-chain disulfides. The main difference in this ADC, in comparison with TDM-I, is the use of a degradable linker and DNA destructive agent. Duocarmycins are strong DNA alkylating agents that bind to the DNA groove and cause adenine N3 alkylation $^{[117]}$. Peptide degradable linkers have good systemic stability. Proteolytic release occurs via cathepsin B and L, creating a self-decomposing shortlived intermediate. This ADC has entered phase 1 of clinical trial in solid cancers, which then enters the expansion phase in HER2-positive tumors.

ADCT-502 is an ADC with engineered trastuzumab attached to highly cytotoxic PBDbased linker-drug tesirine. ADCT-502 is currently being evaluated in patients with solid tumors expressing HER2 in phase 1 of clinical trial. Other ADCs, with different targets and in the final stages of clinical trials are as follows:

\section{Glembatumumab vedotin}

GPNMB is a transmembrane glycoprotein that its role in cancer is complicated; It acts like a tumor suppressor or has a function in the cancer progression. In cancer, GPNMB overexpression is found in different types of tumors, including melanoma, breast, lung, and osteosarcoma, when compared to normal tissues ${ }^{[126-129]}$. In breast cancer, GPNMB gene expression is associated with reduced overall survival. GPNMB overexpression is observed in both TNBC and basal cancers, which is associated with poor $\operatorname{prognosis}^{[130]}$.

Glembatumumab vedotin (CDX-011) is an antiGPNMB ADC containing an IgG2 connected to a microtubule inhibitor, $\mathrm{MMAE}^{[131]}$, through a vc linker ${ }^{[132,133]}$. In a study of phase 2 clinical trials in patients with advanced cancer or local metastasis of breast cancer, Glembatumumab vedotin had more acceptable results when comparing to chemotherapy. Additionally, it had fewer side effects in patients with less stimulation of bleeding, itching, neuropathy, and alopecia $^{[134]}$. 


\section{IMMU-132}

The TROP-2 is a membrane glycoprotein overexpressed in a variety of tumors, including breast cancers. Excessive expression of TROP-2 is observed in invasive disease, linked with drug resistance and poor prognosis ${ }^{[135-137]}$. IMMU-132 (Sacituzumab govitecan) is an anti-TROP-2 ADC consisting of one IgG1 anti-TROP-2 mAb (hRS7) and one topoisomerase inhibitor. Unlike other ADCs, $\mathrm{SN}-38$, is a topoisomerase I inhibitor having a moderate effect (nM) when comparing to other drugs currently used in ADC $(<200 \mathrm{pM})$. Second, its releasing mechanism is dependent on acid, which exerts through a benzyl carbonate bond to $\mathrm{SN}-38$ 's lactone ring. This linker contains a short sequence of PEG and a lysine residual, making it relatively polar in nature. It would likely explain the high level of 7.6 DAR in this ADC, which is twice the current ADCs. In PH near 5.3 of lysozyme (37 centigrade), $50 \%$ of the drug is released in 13 hours. IMMU- 132 preclinical models have shown specific antigen activity against TROP- 2-expressing cells in different in vitro and in vivo ${ }^{[136,138]}$.

\section{SAR566658}

CA6 is a tumor-related antigen and one sialoglycotope of MUC1. It is thought that it results from inappropriate MUC1 glycolysis ${ }^{[139]}$. The CA6 cancer-related glycotype is observed in most normal tissues at low levels, whereas its overexpression has been found in many solid tumors, including $30 \%$ of breast cancer cases ${ }^{[139,140]}$. SAR566658 contains an anti-CA6 (huDS6) antibody that binds to a non-polar S-methyl-DM4 drug through a stable disulfide bond ${ }^{[141]}$. Two methyl groups close to disulfide in these linkers are to prevent the breakdown of the linker by free thiols in the bloodstream, while allowing the breakdown in the existence of a much higher level of glutathione and cysteine inside the cytosol or nucleus $^{[142]}$. This ADC has indicated an acceptable immune and antitumor activity during phase 1 of clinical trial in acceleration dose of patient's different solid tumors with CA6 (more than $30 \%$ of tumor cells) expression $^{[143]}$. One phase 2 clinical trial is being conducted in TNBC patients with CA6 expression (NCT 02984683). Numerous ADCs are involved in phase 1 trials targeting breast tumor-related antigens.

\section{LIV-1}

LIV-1 (SLC39A6) is a transmembrane protein that transports zinc into cells ${ }^{[144]}$. LIV-1 regulates estrogen in breast cancer, which its expression has been linked to tumor development and metastasis ${ }^{[145,146]}$. LIV-1 expression is associated with E-cadherin decrease and may play a role in epithelial-mesenchymal transmission and increased metastasis ${ }^{[147,148]}$. The antimLIV2 mouse mAb precisely binds to an extracellular $\mathrm{N}$-terminus epitope of LIV-1. Complementaritydetermining region grafting was used to produce antiLIV-1 human IgG1, named hLIV22. ADC guided to the (SGN-LIV1A) LIV1 side is produced by hLIV22 mAb connection to a MMAE (an analog auristatin) via endogenous cysteine. SGN-LIV1A leads to the elimination of ER- and LIV1-positive MCF7 breast cancer cells, as well as BR0555, which is a xenograft tumor of the breast cell ${ }^{[149]}$. SGN-LIV1A alone and in combination with trastuzumab are currently undergoing phase 1 clinical trial in patients with metastatic breast cancer expressing LIV1.

\section{PTK7}

PTK7 is identified as the colon carcinoma kinase 4, a highly protected PTK that plays an important role in Wnt signaling. In breast cancer, PTK7 is more expressed in ER-negative tumors than in ER-positive tumors. Moreover, PTK7 suppression through siRNA leads to severe inhibition of human ER-negative breast cancer growth ${ }^{[150]}$. An anti-PTK ADC with average DAR of 4, alongside a conjugated h6M24, human (IgG1) mAab, is connected to Aur0101, an auristatin analog, using a decomposable linker (vc-PABC). This ADC is called h6 M24-vc-0101 or PF-06647020. Aur0101 is specifically designed to maintain cellular potential and oxidative metabolism faster than $\mathrm{MMAE}^{[151]}$. Increased clearance of this cytotoxic drug may reduce systemic toxicity and increase ADC therapeutic indicators. PF-06647020 produces antigendependent cytotoxicity in PTK7-expressive cells, leading to the cessation of cell mitosis and destruction of the microtubule. Studies in TNBC models of NOD/SCID rats have shown a high anti-tumor activity of this ADC. Preclinical anti-tumor activity of acceptable immunity and PF-06647020 pharmacokinetic profiles lead to the entrance of ADC to the first phase of clinical trial studies in patients with advanced solid tumors and different expressions of PTK7. Later, it entered to cohort studies in TNBC, non-small-cell lung cancer, and ovarian cancer patients ${ }^{[152]}$.

\section{LAMP-1}

LAMP-1 (CD107a) and LAMP-2 are transmembrane type I proteins, accounting for about $50 \%$ of all lysosomal membrane proteins ${ }^{[153]}$. In normal cells, LAMP-1 is normally expressed in lysosomes, though it is transferred to the surface of tumor cells, where its expression level is associated with invasion and metastasis of different types of tumors ${ }^{[154]}$. SAR428926 is a LAMP1 ADC in which Ab-1 is connected to the 
LAMP1 luminal domain. This antibody does not detect LAMP1 in normal tissue cells. SAR428926 connects to DM4 using a decomposable link, N-succinimidyl-4-(2pyridyldithio) butanoate. SAR428926 assessment of subcutaneous patient-derived xenograft mouse models indicate increased antigen-dependent anti-tumor activity, including shrinkage of breast, prostate, colorectal, lung, and ovarian tumors. The reported activity is related to the LAMP-1 level of expression and the tumor model sensitivity to the DM4 ${ }^{[155,156]}$. Pcadherin has a major role in calcium-dependent cellcell adhesion. It is expressed during growth and also in normal myoepithelial/basal cells of adults and epithelial tumors. In a normal breast, P-cadherin is involved in maintaining the breast epithelium structural integrity in the adult tissues of basal layer and hair follicles ${ }^{[157-159]}$. In breast cancer, P-cadherin overexpression is related to the invasive power of tumors and is a hallmark of poor prognosis ${ }^{[129]}$. PCA062 is an anti-P-cadherin ADC in which an IgG1 is connected to a maytansinoid DMI. PCA 062 is rapidly internalized inside the cell and then lysosome, leading to antigen-dependent cell toxicity. PCA062 ADC has anti-tumor activity in breast and bladder cancer xenograft models ${ }^{[160]}$. At present, PCA062 is evaluated in phase 1 clinical trial in TNBC patients with P-cadherin expression.

\section{EphA4}

Ephrin receptors, from RTK family, have an increased expression in tumors and are related to the development of different types of tumors, including breast, pancreatic and lung cancer ${ }^{[161,162]}$. Expression profiles of PDX models show an increase in the EphA4 expression of TNBC tumors, as compared with adjacent natural breast tissue and other breast cancer subtypes $^{[163]}$. PF-06647263 is an anti-EphA4 ADC in which calicheamicin, DNA destructive agent, binds to an IgG1, anti-EphA4 mAb. It has been introduced to the market as Mylotarg® (Gemtuzumab ozogamicin $)^{[164]}$.

\section{Conclusions and future directions}

Immunotherapy has shown great potential for breast cancer treatment, demonstrating the possibility of utilizing the immune system for clinical benefit in this malignancy. The developments in targeted immunotherapy have led to clinical advances in the treatment of breast tumors. In near-term future, the advances in combination immunotherapies can alter breast cancers from immunologically cold tumors to immune-activated lesions ready for response to immunotherapy. Several strategies that utilize molecular targeted agents to boost breast cancer- specific immunity are under rapid development. In addition, combinatorial approaches that act on the compensatory pathways in resistant lesions may markedly raise hope on the effectiveness and duration of response to immune-based breast cancer prevention.

CONFLICT OF INTEREST. None declared.

\section{REFERENCES}

1. Al Tamimi DM, Shawarby MA, Ahmed A, Hassan AK, AlOdaini AA. Protein expression profile and prevalence pattern of the molecular classes of breast cancer-a Saudi population based study. BMC cancer 2010; 10(1): Article number 223.

2. Stewart BW, Wild CP. World Cancer Report 2014. France: International agency for research on cancer world health organization (IARC); 2014.

3. Pisani P, Parkin D, Ferlay J. Estimates of the worldwide mortality from eighteen major cancers in 1985. Implications for prevention and projections of future burden. International journal of cancer 1993; 55(6): 891-903.

4. Parkin DM. Cancer Incidence in Five Continents. France: International agency for research on cancer world health organization (IARC); 1997.

5. Taghavi A, Fazeli Z, Vahedi M, Baghestani AR, Pourhoseingholi A, Barzegar F, Pourhoseingholi MA. Increased trend of breast cancer mortality in Iran. Asian pacific journal of cancer prevention 2012; 13(1): 367370.

6. Yavari P, Mosavizadeh M, Sadrol-Hefazi B, Mehrabi Y. Reproductive characteristics and the risk of breast cancer--a case-control study in Iran. Asian pacific journal of cancer prevention 2005; 6(3): 370-375.

7. Makki J. Diversity of breast carcinoma: Histological subtypes and clinical relevance. Clinical medicine insights: Pathology 2015; 8: 23-31.

8. Perou CM, Sørlie T, Eisen MB, Van De Rijn M, Jeffrey SS, Rees CA, Pollack JR, Ross DT, Johnsen H, Akslen LA, Fluge O, Pergamenschikov A, Williams C, Zhu SX, Lønning PE, Børresen-Dale AL, Brown PO, Botstein D. Molecular portraits of human breast tumours. Nature 2000; 406(6797): 747-752.

9. American Cancer Society. Breast Cancer Facts and Figures 2019-2020. Reterieved from: https://www. cancer.org/content/dam/cancer-org/research/cancer-facts -and-statistics/breast-cancer-facts-and-figures/breastcancer-facts-and-figures-2019-2020.pdf.

10. Cserni G. Histological type and typing of breast carcinomas and the WHO classification changes over time. Pathologica-journal of the italian society of anatomic pathology and diagnostic cytopathology 2020; 112(1): 25-41.

11. Howlader N, Cronin KA, Kurian AW, Andridge R. Differences in breast cancer survival by molecular subtypes in the United States. Cancer epidemiology and prevention biomarkers 2018; 27(6): 619-626. 
12. Parise CA, Caggiano V. Risk of mortality of nodenegative, ER/PR/HER2 breast cancer subtypes in T1, $\mathrm{T} 2$, and $\mathrm{T} 3$ tumors. Breast cancer research and treatment 2017; 165(3): 743-750.

13. Sharma P. Biology and management of patients with triple-negative breast cancer. The oncologist 2016; 21(9): 1050-1062.

14. Plevritis SK, Munoz D, Kurian AW, Stout NK, Alagoz O, Near AM, Lee SJ, Van Den Broek JJ, Huang X, Schechter CB, Sprague BL, Song J, de Koning HJ, Trentham-Dietz A, van Ravesteyn NT, Gangnon R, Chandler Y, Li Y, Xu C, Ergun MA, Huang H, Berry DA, Mandelblatt JS. Association of screening and treatment with breast cancer mortality by molecular subtype in US women. JAMA 2018; 319(2): 154-164.

15. Wolff AC, Tung NM, Carey LA. Implications of neoadjuvant therapy in human epidermal growth factor receptor 2-positive breast cancer. American society of clinical oncology 2019; 37(25): 2189-2192.

16. Hanahan D, Weinberg RA. Hallmarks of cancer: the next generation Cell 2011; 144(5): 646-674.

17. Swoboda A, Nanda R. Immune checkpoint blockade for breast cancer. Optimizing breast cancer management Cancer treatment and research 2018; 173: 155-165.

18. Zhang X, Kim S, Hundal J, Herndon JM, Li S, Petti AA, Soysal SD, Li L, McLellan MD, Hoog J, Primeau T, Myers N, Vickery TL, Sturmoski M, Hagemann IS, Miller CA, Ellis MJ, Mardis ER, Hansen T, Fleming TP, Goedegebuure SP, Gillanders WE. Breast cancer neoantigens can induce $\mathrm{CD}^{+} \mathrm{T}$-cell responses and antitumor immunity. Cancer immunology research 2017; 5(7): 516-523.

19. Ayoub NM, Al-Shami KM, Yaghan RJ. Immunotherapy for HER2-positive breast cancer: recent advances and combination therapeutic approaches. Breast cancer 2019; 11: 53-69.

20. Shin SU, Lee J, Kim JH, Kim WH, Song SE, Chu A, Kim HS, Han W, Ryu HS, Moon WK. Gene expression profiling of calcifications in breast cancer. Scientific reports 2017; 7: 427.

21. Toraya-Brown S, Fiering S. Local tumour hyperthermia as immunotherapy for metastatic cancer. International journal of hyperthermia 2014; 30(8): 531-539.

22. Yagawa Y, Tanigawa K, Kobayashi Y, Yamamoto M. Cancer immunity and therapy using hyperthermia with immunotherapy, radiotherapy, chemotherapy, and surgery. Journal cancer metastasis treatment 2017; 3(10): 218-230.

23. Zagar TM, Oleson JR, Vujaskovic Z, Dewhirst MW, Craciunescu OI, Blackwell KL, Prosnitz LR, Jones EL. Hyperthermia for locally advanced breast cancer. International journal of hyperthermia 2010; 26(7): 618624.

24. Mostafa AA, Codner D, Hirasawa K, Komatsu Y, Young MN, Steimle V, Drover S. Activation of ER $\alpha$ signaling differentially modulates IFN- $\gamma$ induced HLAclass II expression in breast cancer cells. PLoS one 2014; 9(1): e87377.

25. Pietras RJ. Interactions between estrogen and growth factor receptors in human breast cancers and the tumor-associated vasculature. The breast journal 2003; 9(5): 361-373.

26. Hühn D, Martí-Rodrigo $\mathrm{P}$, Mouron S, Hansel C, Tschapalda K, Haggblad M, Lidemalm L, QuintelaFandino MA, Carreras-Puigvert J, Fernandez-Capetillo O. Estrogen deprivation triggers an immunosuppressive phenotype in breast cancer cells. bioRxiv 2019; doi: https://doi.org/10.1101/715136.

27. Gabrilovich DI, Ishida T, Nadaf S, Ohm JE, Carbone DP. Antibodies to vascular endothelial growth factor enhance the efficacy of cancer immunotherapy by improving endogenous dendritic cell function. Clinical cancer research 1999; 5(10): 2963-2970.

28. Hahn T, Akporiaye E. Targeting transforming growth factor $\beta$ to enhance cancer immunotherapy. Current oncology 2006; 13(4): 141-143.

29. Peddi PF, Hurvitz SA. Trastuzumab emtansine: the first targeted chemotherapy for treatment of breast cancer. Future oncology 2013; 9(3): 319-326.

30. Mavratzas A, Seitz J, Smetanay K, Schneeweiss A, Jäger D, Fremd C. Atezolizumab for use in PD-L1positive unresectable, locally advanced or metastatic triple-negative breast cancer. Future oncology 2020; 16(3): 4439-4453.

31. García-Aranda M, Redondo $M$. Targeting protein kinases to enhance the response to anti-PD-1/PD-11 immunotherapy. International journal of molecular sciences 2019; 20(9): 2296.

32. García-Aranda M, Pérez-Ruiz E, Redondo M. Bcl-2 inhibition to overcome resistance to chemo-and immunotherapy. International journal of molecular sciences 2018; 19(12): 3950.

33. García-Aranda M, Redondo M. Protein kinase targets in breast cancer. International journal of molecular sciences 2017; 18(12): 2543.

34. Lee HJ, Song IH, Park IA, Heo SH, Kim YA, Ahn JH, Gong G. Differential expression of major histocompatibility complex class I in subtypes of breast cancer is associated with estrogen receptor and interferon signaling. Oncotarget 2016; 7(21): 3011930132 .

35. Redondo M, García J, Villar E, Rodrigo I, Perea-Milla E, Serrano A, Morell M. Major histocompatibility complex status in breast carcinogenesis and relationship to apoptosis. Human pathology 2003; 34(12): 12831289.

36. Makhoul I, Atiq M, Alwbari A, Kieber-Emmons T. Breast cancer immunotherapy: An update. Breast cancer (Auckland) 2018; 12: 1178223418774802.

37. Axelrod ML, Cook RS, Johnson DB, Balko JM. Biological consequences of MHC-II expression by tumor cells in cancer. Clinical cancer research 2019; 25(8): 2392-2402.

38. Forero A, Li Y, Chen D, Grizzle WE, Updike KL, Merz ND, Downs-Kelly E, Burwell TC, Vaklavas C, Buchsbaum DJ, Myers RM, LoBuglio AF, Varley KE. Expression of the MHC class II pathway in triplenegative breast cancer tumor cells is associated with a good prognosis and infiltrating lymphocytes. Cancer immunology research 2016; 4(5): 390-399. 
39. Chaganty BK, Lu Y, Qiu S, Somanchi SS, Lee DA, Fan Z. Trastuzumab upregulates expression of HLA-ABC and $\mathrm{T}$ cell costimulatory molecules through engagement of natural killer cells and stimulation of IFN- $\gamma$ secretion. Oncoimmunology 2016; 5(4): e1100790.

40. Inoue $M$, Mimura K, Izawa S, Shiraishi K, Inoue A, Shiba S, Watanabe M, Maruyama T, Kawaguchi Y, Inoue S, Kawasaki T, Choudhury A, Katoh R, Fujii H, Kiessling R, Kono K. Expression of MHC class I on breast cancer cells correlates inversely with HER2 expression. Oncoimmunology 2012; 1(7): 11041110 .

41. Makhoul I. Therapeutic Strategies for Breast Cancer. In: Bland K. I., Copeland E. M., Klimberg V. S., Gradishar W. J., editors. The Breast; the Netherland: Elsevier: 2018. p. 315-330.

42. Tao JJ, Visvanathan K, Wolff AC. Long term side effects of adjuvant chemotherapy in patients with early breast cancer. Breast 2015; 24 Suppl 2(0 2): S149S153.

43. Couzin-Frankel J. Cancer immunotherapy. Science 2013; 342(6165): 1432-1433.

44. Ferrara N. Vascular endothelial growth factor as a target for anticancer therapy. The oncologist 2004; 9 Suppl 1: 2-10.

45. Bertrand A, Kostine M, Barnetche T, Truchetet ME, Schaeverbeke T. Immune related adverse events associated with anti-CTLA-4 antibodies: systematic review and meta-analysis. BMC medicine 2015; 13: 211.

46. Intlekofer AM, Thompson CB. At the bench: preclinical rationale for CTLA-4 and PD-1 blockade as cancer immunotherapy. Journal of leukocyte biology 2013; 94(1): 25-39.

47. Muenst S, Soysal S, Gao F, Obermann E, Oertli D, Gillanders W. The presence of programmed death 1 (PD-1)-positive tumor-infiltrating lymphocytes is associated with poor prognosis in human breast cancer. Breast cancer research and treatment 2013; 139(3): 667-676.

48. Qin T, Zeng YD, Qin G, Xu F, Lu JB, Fang WF, Xue C, Zhan JH, Zhang XK, Zheng QF, Peng RJ, Yuan ZY, Zhang L, Wang SS. High PD-L1 expression was associated with poor prognosis in 870 Chinese patients with breast cancer. Oncotarget 2015; 6(32): 3397233981.

49. Sun WY, Lee YK, Koo JS. Expression of PD-L1 in triple-negative breast cancer based on different immunohistochemical antibodies. Journal of translational medicine 2016; 14(1): 173.

50. Nanda R, Chow LQ, Dees EC, Berger R, Gupta S, Geva R, Pusztai L, Pathiraja K, Aktan G, Cheng JD, Karantza $\mathrm{V}$, Buisseret L. Pembrolizumab in patients with advanced triple-negative breast cancer: phase $\mathrm{Ib}$ keynote-012 study. Journal of Clinical oncology 2016; 34(21): 2460.

51. Adams S, Diamond JR, Hamilton EP, Pohlmann PR, Tolaney SM, Molinero L, He X, Waterkamp D, Funke $\mathrm{R}$, Powderly J. Phase $\mathrm{Ib}$ trial of atezolizumab in combination with nab-paclitaxel in patients with metastatic triple-negative breast cancer (mTNBC).
Journal of clinical oncology 2016; 34(Suppl): abstr 1009.

52. Apolo AB, Infante JR, Hamid O, Patel M, Wang D, Kelly K, Mega A, Britten CD, Mita A, Ravaud A, Cuillerto JM, Von Heydebreck A, Gulley JL. 2630 Avelumab (MSB0010718C), an anti-PD-L1 antibody, in patients with locally advanced or metastatic urothelial carcinoma: a phase Ib trial. European journal of cancer 2015; 51(3): S522.

53. Palucka K, Banchereau J. Dendritic-cell-based therapeutic cancer vaccines. Immunity 2013; 39(1): 3848.

54. Sharma P, Allison JP. Immune checkpoint targeting in cancer therapy: toward combination strategies with curative potential. Cell 2015; 161(2): 205-214.

55. Criscitiello C. Tumor-associated antigens in breast cancer. Breast care 2012; 7(4): 262-266.

56. Sharma A, Koldovsky U, Xu S, Mick R, Roses R, Fitzpatrick E, Weinstein S, Nisenbaum H, Levine BL, Fox K, Zhang P, Koski G, Czerniecki BJ. HER-2 pulsed dendritic cell vaccine can eliminate HER-2 expression and impact ductal carcinoma in situ. Cancer 2012; 118(17): 4354-4362.

57. Heery CR, Ibrahim NK, Arlen PM, Mohebtash M, Murray JL, Koenig K, Madan RA, McMahon S, Marté JL, Steinberg SM, Donahue RN, Grenga I, Jochems C, Farsaci B, Folio LR, Schlom J, Gulley JL. Docetaxel alone or in combination with a therapeutic cancer vaccine (PANVAC) in patients with metastatic breast cancer: a randomized clinical trial. JAMA oncology 2015; 1(8): 1087-1095.

58. Nemunaitis J. Vaccines in cancer: GVAX®, a Gv MCSF gene vaccine. Expert review of vaccines 2005; 4(3): 259-274.

59. Datta J, Terhune JH, Lowenfeld L, Cintolo JA, Xu S, Roses RE, Czerniecki BJ. Optimizing dendritic cellbased approaches for cancer immunotherapy. The yale journal of biology and medicine 2014; 87(4): 491-518.

60. Vasir B, Wu Z, Crawford K, Rosenblatt J, Zarwan C, Bissonnette A, Kufe D, Avigan D. Fusions of dendritic cells with breast carcinoma stimulate the expansion of regulatory $\mathrm{T}$ cells while concomitant exposure to IL-12, $\mathrm{CpG}$ oligodeoxynucleotides, and anti-CD3/CD28 promotes the expansion of activated tumor reactive cells. The Journal of immunology 2008; 181(1): 808821.

61. de Paula Peres L, da Luz FAC, dos Anjos Pultz B, Brígido PC, de Araújo RA, Goulart LR, Silva MJB. Peptide vaccines in breast cancer: The immunological basis for clinical response. Biotechnology advances 2015; 33(8): 1868-1877.

62. Slingluff CL Jr. The present and future of peptide vaccines for cancer: single or multiple, long or short, alone or in combination? Cancer journal 2011; 17(5): 343-350.

63. Mitchison N. Studies on the immunological response to foreign tumor transplants in the mouse I. The role of lymph node cells in conferring immunity by adoptive transfer. Journal of experimental medicine 1955; 102(2): $157-177$. 
64. Dudley ME, Wunderlich JR, Shelton TE, Even J, Rosenberg SA. Generation of tumor-infiltrating lymphocyte cultures for use in adoptive transfer therapy for melanoma patients. Journal of immunotherapy 2003; 26(4): 332-342.

65. Stanton SE, Disis ML. Clinical significance of tumorinfiltrating lymphocytes in breast cancer. Journal for immunotherapy of cancer 2016; 4(1): 59.

66. Feins S, Kong W, Williams EF, Milone MC, Fraietta JA. An introduction to chimeric antigen receptor (CAR) T-cell immunotherapy for human cancer. American journal of hematology 2019; 94(1): 3-9.

67. Sharpe M, Mount N. Genetically modified T cells in cancer therapy: opportunities and challenges. Disease models and mechanisms 2015; 8(4): 337-350.

68. Fesnak AD, June CH, Levine BL. Engineered T cells: the promise and challenges of cancer immunotherapy. Nature reviews cancer 2016; 16(9): 566-581.

69. Lee HJ, Kim JY, Song IH, Park IA, Yu JH, Gong G. Expression of NY-ESO-1 in triple-negative breast cancer is associated with tumor-infiltrating lymphocytes and a good prognosis. Oncology 2015; 89(6): 337-344.

70. Chandran S, Ma J, Klatt MG, Dündar F, Zumbo P, Femia MR, Betel D, Scheinberg DA, Baker BM, Klebanoff CA. (2019, October 25-28). Abstract CN0103: $\mathrm{T}$ cell receptor gene therapy for a public neoantigen derived from mutated PIK3CA, a dominant driver oncogene in breast and endometrial cancers [Conference presentation abstract]. AACR-NCI-EORTC International Conference on Molecular Targets and Cancer Therapeutics; October 26-30, 2019; Boston, MA, United States.

71. Newick K, Moon E, Albelda SM. Chimeric antigen receptor T-cell therapy for solid tumors. Molecular therapy-oncolytics 2016; 3: 16006.

72. Posey Jr AD, Schwab RD, Boesteanu AC, Steentoft C, Mandel U, Engels B, Stone JD, Madsen TD, Schreiber K, Haines KM, Cogdill AP, Chen TJ, Song D, Scholler J, Kranz DM, Feldman MD, Young R, Keith B, Schreiber H, Clausen H, Johnson LA, June CH. Engineered CAR T cells targeting the cancer-associated Tn-glycoform of the membrane mucin MUC1 control adenocarcinoma. Immunity 2016; 44(6): 1444-1454.

73. Song DG, Ye Q, Poussin M, Chacon JA, Figini M, Powell DJ. Effective adoptive immunotherapy of triplenegative breast cancer by folate receptor-alpha redirected CAR T cells is influenced by surface antigen expression level. Journal of hematology and oncology 2016; 9(1): 56

74. Wilkie S, van Schalkwyk MC, Hobbs S, Davies DM, van der Stegen SJ, Pereira ACP, Burbridge SE, Box C, Eccles SA, Maher J. Dual targeting of ErbB2 and MUC1 in breast cancer using chimeric antigen receptors engineered to provide complementary signaling. Journal of clinical immunology 2012; 32(5): 1059-1070.

75. Rosenberg SA, Yang JC, Sherry RM, Kammula US, Hughes MS, Phan GQ, Citrin DE, Restifo NP, Robbins $\mathrm{PF}$, Wunderlich JR, Morton KE, Laurencot CM, Steinberg SM, White DE. Durable complete responses in heavily pretreated patients with metastatic melanoma using T-cell transfer immunotherapy. Clinical cancer research 2011; 17(13): 4550-4557.

76. Moreno Ayala MA, Gottardo MF, Asad AS, Zuccato C, Nicola A, Seilicovich A, Candolfi M. Immunotherapy for the treatment of breast cancer. Expert opinion on biological therapy 2017; 17(7): 797-812.

77. Fiszman GL, Jasnis MA. Molecular mechanisms of trastuzumab resistance in HER2 overexpressing breast cancer. International journal of breast cancer 2011; 2011:352182.

78. Munagala R, Aqil F, Gupta RC. Promising molecular targeted therapies in breast cancer. Indian journal of pharmacology 2011; 43(3): 236-245.

79. Gu G, Dustin D, Fuqua SA. Targeted therapy for breast cancer and molecular mechanisms of resistance to treatment. Current opinion in pharmacology 2016; 31: 97-103.

80. Bose R, Kavuri SM, Searleman AC, Shen W, Shen D, Koboldt DC, Monsey J, Goel N, Aronson AB, Li S, Ma CX, Ding L, Mardis ER, Ellis MJ. Activating HER2 mutations in HER2 gene amplification negative breast cancer. Cancer discovery 2013; 3(2): 224-237.

81. Dave B, Migliaccio I, Gutierrez MC, Wu MF, Chamness GC, Wong H, Narasanna A, Chakrabarty A, Hilsenbeck SG, Huang J, Rimawi M, Schiff R, Arteaga C, Osborne CK, Chang JC. Loss of phosphatase and tensin homolog or phosphoinositol-3 kinase activation and response to trastuzumab or lapatinib in human epidermal growth factor receptor 2-overexpressing locally advanced breast cancers. Journal of clinical oncology 2011; 29(2): 166-173.

82. Wang Y, Liu Y, Du Y, Yin W, Lu J. The predictive role of phosphatase and tensin homolog (PTEN) loss, phosphoinositol-3 (PI3) kinase (PIK3CA) mutation, and PI3K pathway activation in sensitivity to trastuzumab in HER2-positive breast cancer: a meta-analysis. Current medical research and opinion 2013; 29(6): 633-642.

83. Kayl AE, Meyers CA. Side-effects of chemotherapy and quality of life in ovarian and breast cancer patients. Current opinion in obstetrics and gynecology 2006; 18(1): 24-28.

84. Swain SM, Baselga J, Kim S-B, Ro J, Semiglazov V, Campone M, Ciruelos E, Ferrero J-M, Schneeweiss A, Heeson S, Clark E, Ross G, Benyunes MC, Cortés J, CLEOPATRA Study Group. Pertuzumab, trastuzumab, and docetaxel in HER2-positive metastatic breast cancer. New England journal of medicine 2015; 372(8): 724-734.

85. Arnould L, Gelly M, Penault-Llorca F, Benoit L, Bonnetain F, Migeon C, Cabaret V, Fermeaux V, Bertheau P, Garnier J, Jeannin JF, Coudert B. Trastuzumab-based treatment of HER2-positive breast cancer: an antibody-dependent cellular cytotoxicity mechanism? British journal of cancer 2006; 94(2): 259267.

86. Hudis CA. Trastuzumab-mechanism of action and use in clinical practice. New England journal of medicine 2007; 357(1): 39-51.

87. Claret FX, Vu TT. Trastuzumab: updated mechanisms 
of action and resistance in breast cancer. Frontiers in oncology 2012; 2: 62.

88. Rimawi MF, Wiechmann LS, Wang Y-C, Huang C, Migliaccio I, Wu M-F, Gutierrez C, Hilsenbeck SG, Arpino G, Massarweh S, Ward R, Soliz R, Osborne CK, Schiff R. Reduced dose and intermittent treatment with lapatinib and trastuzumab for potent blockade of the HER pathway in HER2/neu-overexpressing breast tumor xenografts. Clinical cancer research 2011; 17(6): 1351-1361.

89. Gradishar WJ, Anderson BO, Balassanian R, Blair SL, Burstein HJ, Cyr A, Elias AD, Farrar WB, Forero A, Giordano SH, Goetz M, Goldstein LJ, Hudis CA, Isakoff SJ, Marcom PK, Mayer IA, McCormick B, Moran M, Patel SA, Pierce LJ, Reed EC, Salerno KE, Schwartzberg LS, Smith Kl, Smith ML, Soliman H, Somlo G, Telli M, Ward JH, Shead DA, Kumar R. NCCN guidelines insights breast cancer, version 1.2016. Journal of the national comprehensive cancer network 2015; 13(12): 1475-1485.

90. Johnston SR. Enhancing endocrine therapy for hormone receptor-positive advanced breast cancer: cotargeting signaling pathways. Journal of the national cancer institute 2015; 107(10).

91. Krop IE, Mayer IA, Ganju V, Dickler M, Johnston S, Morales S, Yardley DA, Melichar B, Forero-Torres A, Lee SC, De Boer RH, Petrakova K, Vallentin S, Perez EA, Piccart M, Ellis M, Winer E, Gendreau S, Derynck M, Lackner M, Levy G, Qiu J, He J, Schmid P. Pictilisib for oestrogen receptor-positive, aromatase inhibitorresistant, advanced or metastatic breast cancer (FERGI): a randomised, double-blind, placebo-controlled, phase 2 trial. The lancet oncology 2016; 17(6): 811-821.

92. Brufsky AM, Hurvitz S, Perez E, Swamy R, Valero V, O'Neill V, Rugo HS. RIBBON-2: A randomized, double-blind, placebo-controlled, phase III trial evaluating the efficacy and safety of bevacizumab in combination with chemotherapy for second-line treatment of human epidermal growth factor receptor 2 negative metastatic breast cancer. Journal of clinical oncology 2011; 29(32): 4286-4293.

93. Robert NJ, Diéras V, Glaspy J, Brufsky AM, Bondarenko I, Lipatov ON, Perez EA, Yardley DA, Chan SY, Zhou X, Phan SC, O'Shaughnessy J. RIBBON-1: randomized, double-blind, placebocontrolled, phase III trial of chemotherapy with or without bevacizumab for first-line treatment of human epidermal growth factor receptor 2-negative, locally recurrent or metastatic breast cancer. Journal of clinical oncology 2011; 29(10): 1252-1260.

94. Baselga J, Costa F, Gomez H, Hudis CA, Rapoport B, Roche H, Schwartzberg LS, Petrenciuc O, Shan M, Gradishar WJ. A phase 3 tRial comparing capecitabinE in combination with SorafenIb or pLacebo for treatment of locally advanced or metastatIc HER2-Negative breast CancEr (the RESILIENCE study): study protocol for a randomized controlled trial. Trials 2013; 14(1): 228.

95. Mackey JR, Ramos-Vazquez M, Lipatov O, McCarthy N, Krasnozhon D, Semiglazov V, Manikhas A, Gelmon KA, Konecny GE, Webster M, Hegg R, Verma S,
Gorbunova V, Abi Gerges D, Thireau F, Fung H, Simms L, Buyse M, Ibrahim A, Martin M. Primary results of ROSE/TRIO-12, a randomized placebocontrolled phase III trial evaluating the addition of ramucirumab to first-line docetaxel chemotherapy in metastatic breast cancer. Journal of clinical oncology: official journal of the american society of clinical oncology 2015; 33(2): 141-148.

96. Baselga J, Trigo JM, Bourhis J, Tortochaux J, CortésFunes H, Hitt R, Gascón P, Amellal N, Harstrick A, Eckardt A. Phase II multicenter study of the antiepidermal growth factor receptor monoclonal antibody cetuximab in combination with platinum-based chemotherapy in patients with platinum-refractory metastatic and/or recurrent squamous cell carcinoma of the head and neck. Journal of clinical oncology 2005; 23(24): 5568-5577.

97. Carey LA, Rugo HS, Marcom PK, Mayer EL, Esteva FJ, Ma CX, Liu MC, Storniolo AM, Rimawi MF, Forero-Torres A, Wolff AC, Hobday TJ, Ivanova A, Chiu WK, Ferraro M, Burrows E, Bernard PS, Hoadley KA, Perou CM, Winer EP. TBCRC 001: randomized phase II study of cetuximab in combination with carboplatin in stage IV triple-negative breast cancer. Journal of clinical oncology 2012; 30(21): 2615-2623.

98. Klein CA. Selection and adaptation during metastatic cancer progression. Nature 2013; 501(7467): 365-372.

99. Roukos DH. Beyond HER2 and trastuzumab: heterogeneity, systems biology, and cancer origin research may guide the future for personalized treatment of very early but aggressive breast cancer. Journal of clinical oncology: official journal of the american society of clinical oncology 2010; 28(17): e279-280.

100. Chames P, Van Regenmortel M, Weiss E, Baty D. Therapeutic antibodies: successes, limitations and hopes for the future. British journal of pharmacology 2009; 157(2): 220-233.

101. Barginear MF, John V, Budman DR. TrastuzumabDM1: a clinical update of the novel antibody-drug conjugate for HER2-overexpressing breast cancer. Molecular medicine 2013; 18(1): 1473-1479.

102. Ducry L, Stump B. Antibody-drug conjugates: linking cytotoxic payloads to monoclonal antibodies. Bioconjugate chemistry 2010; 21(1): 5-13.

103. Senter PD. Potent antibody drug conjugates for cancer therapy. Current opinion in chemical biology 2009; 13(3): 235-344.

104. Bross PF, Beitz J, Chen G, Chen XH, Duffy E, Kieffer L, Roy S, Sridhara R, Rahman A, Williams G, Pazdur R. Approval summary: gemtuzumab ozogamicin in relapsed acute myeloid leukemia. Clinical cancer research 2001; 7(6): 1490-1496.

105. Pro B, Advani R, Brice P, Bartlett NL, Rosenblatt JD, Illidge T, Matous J, Ramchandren R, Fanale M, Connors JM, Yang Y, Sievers EL, Kennedy DA, Shustov A. Brentuximab vedotin (SGN-35) in patients with relapsed or refractory systemic anaplastic large-cell lymphoma: results of a phase II study. Journal of clinical oncology 2012; 30(18): 2190-2196.

106. Amiri-Kordestani L, Blumenthal GM, Xu QC, Zhang L, 
Tang SW, Ha L, Weinberg WC, Chi B, Candau-Chacon R, Hughes P, Russell AM, Miksinski SP, Chen XH, McGuinn WD, Palmby T, Schrieber SJ, Liu Q, Wang J, Song P, Mehrotra N, Skarupa L, Clouse K, Al-Hakim A, Sridhara R, Ibrahim A, Justice R, Pazdur R, Cortazar P .FDA approval: ado-trastuzumab emtansine for the treatment of patients with HER2-positive metastatic breast cancer. Clinical cancer research 2014; 20(17): 4436-4441.

107. Lamb YN. Inotuzumab ozogamicin: first global approval. Drugs 2017; 77(14): 1603-1610

108. Hurvitz SA, Kakkar R. The potential for trastuzumab emtansine in human epidermal growth factor receptor 2 positive metastatic breast cancer: latest evidence and ongoing studies. Therapeutic advances in medical oncology 2012; 4(5): 235-245.

109. Slamon D, Eiermann W, Robert N, Pienkowski T, Martin M, Press M, Mackey J, Glaspy J, Chan A, Pawlicki M, Pinter T, Valero V, Liu MC, Sauter G, von Minckwitz G, Visco F, Bee V, Buyse M, Bendahmane B, Tabah-Fisch I, Lindsay MA, Riva A, Crown J, Breast Cancer International Research Group. Adjuvant trastuzumab in HER2-positive breast cancer. New England journal of medicine 2011; 365(14): 1273-1283.

110. Burris III HA, Tibbitts J, Holden SN, Sliwkowski MX, Phillips GDL. Trastuzumab emtansine (T-DM1): a novel agent for targeting HER2+ breast cancer. Clinical breast cancer 2011; 11(5): 275-282.

111. Phillips GDL, Li G, Dugger DL, Crocker LM, Parsons KL, Mai E, Blättler WA, Lambert JM, Chari RV, Lutz RJ, Wong WL, Jacobson FS, Koeppen H, Schwall RH, Kenkare-Mitra SR, Spencer SD, Sliwkowski MX. Targeting HER2-positive breast cancer with trastuzumab-DM1, an antibody-cytotoxic drug conjugate. Cancer research 2008; 68(22): 9280-9290.

112. Verma S, Miles D, Gianni L, Krop IE, Welslau M, Baselga J, Pegram M, Oh D-Y, Diéras V, Guardino E, Fang L, Lu MW. Trastuzumab emtansine for HER2positive advanced breast cancer. New England journal of medicine 2012; 367(19): 1783-1791.

113. Nakada T, Masuda T, Naito H, Yoshida M, Ashida S, Morita K, Miyazaki H, Kasuya Y, Ogitani Y, Yamaguchi J, Abe Y, Honda T. Novel antibody drug conjugates containing exatecan derivative-based cytotoxic payloads. Bioorganic and medicinal chemistry letters 2016; 26(6): 1542-1545.

114. Ogitani Y, Abe Y, Iguchi T, Yamaguchi J, Terauchi T, Kitamura M, Goto K, Goto M, Oitate M, Yukinaga H, Yabe Y, Nakada T, Masuda T, Morita K, Agatsuma T. Wide application of a novel topoisomerase I inhibitorbased drug conjugation technology. Bioorganic \& medicinal chemistry letters 2016; 26(20): 5069-5072

115. Ogitani Y, Hagihara K, Oitate M, Naito H, Agatsuma T. Bystander killing effect of DS-8201a, a novel anti-human epidermal growth factor receptor 2 antibody-drug conjugate, in tumors with human epidermal growth factor receptor 2 heterogeneity. Cancer science 2016; 107(7): 1039-1046.

116. Wethington SL, Wright JD, Herzog TJ. Key role of topoisomerase I inhibitors in the treatment of recurrent and refractory epithelial ovarian carcinoma. Expert review of anticancer therapy 2008; 8(5): 819-831.

117. Elgersma RC, Coumans RG, Huijbregts T, Menge WM, Joosten JA, Spijker HJ, de Groot FM, van der Lee MM, Ubink R, van den Dobbelsteen DJ, Egging DF, Dokter WH, Verheijden GF, Lemmens JM, Timmers CM, Beusker PH. Design, synthesis, and evaluation of linkerduocarmycin payloads: toward selection of HER2targeting antibody-drug conjugate SYD985. Molecular pharmaceutics 2015; 12(6): 1813-1835.

118. van der Lee MM, Groothuis PG, Ubink R, van der Vleuten MA, van Achterberg TA, Loosveld EM, Damming D, Jacobs DC, Rouwette M, Egging DF, van den Dobbelsteen D, Beusker PH, Goedings $\mathrm{P}$, Verheijden GF, Lemmens JM, Timmers M, Dokter WH. The preclinical profile of the duocarmycin-based HER2targeting ADC SYD985 predicts for clinical benefit in low HER2-expressing breast cancers. Molecular cancer therapeutics 2015; 14(3): 692-703.

119. C Patil P, Satam V, Lee M. A short review on the synthetic strategies of duocarmycin analogs that are powerful DNA alkylating agents. Anti-Cancer agents in medicinal chemistry (formerly current medicinal chemistry-anti-cancer agents) 2015; 15(5): 616-630.

120. Ghosh N, Sheldrake HM, Searcey M, Pors K. Chemical and biological explorations of the family of CC-1065 and the duocarmycin natural products. Current topics in medicinal chemistry 2009; 9(16): 1494-1524.

121. Zammarchi F, Chivers S, Williams DG, Adams L, Mellinas-Gomez M, Tyrer P, Corbett S, D'Hooge F, Dissanayake S, Sims S. ADCT-502, a novel pyrrolobenzodiazepine (PBD)-based antibody-drug conjugate (ADC) targeting low HER2-expressing solid cancers. European journal of cancer 2016; 69: 28.

122. Humphreys RC, Kirtely J, Hewit A, Biroc S, Knudsen N, Skidmore L, Wahl A. Site specific conjugation of ARX-788, an antibody drug conjugate (ADC) targeting HER2, generates a potent and stable targeted therapeutic for multiple cancers. AACR 2015; 75(15)

123.Li JY, Perry SR, Muniz-Medina V, Wang X, Wetzel LK, Rebelatto MC, Hinrichs MJM, Bezabeh BZ, Fleming RL, Dimasi N, Feng H, Toader D, Yuan AQ, $\mathrm{Xu}$ L, Lin J, Gao C, Wu H, Dixit R, Osbourn JK, Coats SR. A biparatopic HER2-targeting antibody-drug conjugate induces tumor regression in primary models refractory to or ineligible for HER2-targeted therapy. Cancer cell 2016; 29(1): 117-129.

124. Thompson P, Fleming R, Bezabeh B, Huang F, Mao S, Chen C, Harper J, Zhong H, Gao X, Yu XQ, Hinrichs MJ, Reed M, Kamal A, Strout P, Cho S, Woods R, Hollingsworth RE, Dixit R, Wu H, Gao C, Dimasi N. Rational design, biophysical and biological characterization of site-specific antibody-tubulysin conjugates with improved stability, efficacy and pharmacokinetics. Journal of controlled release 2016; 236: 100-116.

125. Yurkovetskiy AV, Yin M, Bodyak N, Stevenson CA, Thomas JD, Hammond CE, Qin L, Zhu B, Gumerov DR, Ter-Ovanesyan E, Uttard A, Lowinger TB. A polymer-based antibody-vinca drug conjugate platform: 
Characterization and preclinical efficacy. Cancer research 2015; 75(16) 3365-3372.

126. Maric G, Annis M, Dong Z, Rose A, Ng S, Perkins D, MacDonald P, Ouellet V, Russo C, Siegel P. GPNMB cooperates with neuropilin-1 to promote mammary tumor growth and engages integrin $\alpha 5 \beta 1$ for efficient breast cancer metastasis. Oncogene 2015; 34(43): 54945504.

127. aric G, Rose AA, Annis MG, Siegel PM. Glycoprotein non-metastatic b (GPNMB): A metastatic mediator and emerging therapeutic target in cancer. Oncotargets and therapy 2013; 6: 839 .

128. Roth M, Barris DM, Piperdi S, Kuo V, Everts S, Geller D, Houghton P, Kolb EA, Hawthorne T, Gill J, Gorlick R. Targeting glycoprotein NMB with antibody-drug conjugate, glembatumumab vedotin, for the treatment of Osteosarcoma. Pediatric blood and cancer 2016; 63(1): 32-38.

129. Turashvili G, McKinney SE, Goktepe O, Leung SC, Huntsman DG, Gelmon KA, Los G, Rejto PA, Aparicio SA. P-cadherin expression as a prognostic biomarker in a 3992 case tissue microarray series of breast cancer. Modern Pathology 2011; 24(1): 64-81.

130. Rose AA, Grosset A-A, Dong Z, Russo C, MacDonald PA, Bertos NR, St-Pierre Y, Simantov R, Hallett M, Park M, Gaboury L, Siegel PM. Glycoprotein nonmetastatic $\mathrm{B}$ is an independent prognostic indicator of recurrence and a novel therapeutic target in breast cancer. Clinical cancer research 2010; 16(7): 21472156.

131. Doronina SO, Toki BE, Torgov MY, Mendelsohn BA, Cerveny CG, Chace DF, DeBlanc RL, Gearing RP, Bovee TD, Siegall CB, Francisco JA, Wahl AF, Meyer DL, Senter PD. Development of potent monoclonal antibody auristatin conjugates for cancer therapy. Nature biotechnology 2003; 21(7): 778-784.

132. Katz J, Janik JE, Younes A. Brentuximab vedotin (SGN-35). Clinical cancer research 2011; 17(20): 6428-6436.

133. Younes A, Bartlett NL, Leonard JP, Kennedy DA, Lynch CM, Sievers EL, Forero-Torres A. Brentuximab vedotin (SGN-35) for relapsed CD30-positive lymphomas. New England journal of medicine 2010; 363(19): 1812-1821.

134. Yardley DA, Weaver R, Melisko ME, Saleh MN, Arena FP, Forero A, Cigler T, Stopeck A, Citrin D, Oliff I, Bechhold R, Loutfi R, Garcia AA, Cruickshank S, Crowley E, Green J, Hawthorne T, Yellin MJ, Davis TA, Vahdat LT. Emerge: A randomized phase II study of the antibody-drug conjugate glembatumumab vedotin in advanced glycoprotein NMB-expressing breast cancer. Journal of clinical oncology 2015; 33(14): 16091619.

135. Goldenberg DM, Cardillo TM, Govindan SV, Rossi EA, Sharkey RM. Trop-2 is a novel target for solid cancer therapy with sacituzumab govitecan (IMMU-132), an antibody-drug conjugate (ADC). Oncotarget 2015; 6(26): 22496-22512.

136. Shvartsur A, Bonavida B. Trop2 and its overexpression in cancers: regulation and clinical/therapeutic implications. Genes and cancer 2015; 6(3-4): 84.

137.Zeng P, Chen MB, Zhou LN, Tang M, Liu CY, Lu PH. Impact of TROP2 expression on prognosis in solid tumors: A Systematic review and meta-analysis. Scientific reports 2016; 6: 33658.

138. Cardillo TM, Govindan SV, Sharkey RM, Trisal P, Goldenberg DM. Humanized anti-Trop-2 IgG-SN-38 conjugate for effective treatment of diverse epithelial cancers: preclinical studies in human cancer xenograft models and monkeys. Clinical cancer research 2011; 17(10): 3157-3169.

139. Boni V, Rixe O, Rasco D, Gomez-Roca C, Calvo E, Morris JC, Tolcher AW, Assadourian S, Guillemin H, Delord JP. Abstract A73: A Phase I first-in-human (FIH) study of SAR566658, an anti CA6-antibody drug conjugate (ADC), in patients (Pts) with CA6-positive advanced solid tumors (STs)(NCT01156870). AACR 2013

140. Smith NL, Halliday BE, Finley JL, Wennerberg AEK. The spectrum of immunohistochemical reactivity of monoclonal antibody DS6 in nongynecologic neoplasms. Applied immunohistochemistry and molecular morphology 2002; 10(2): 152-158.

141. Widdison WC, Wilhelm SD, Cavanagh EE, Whiteman KR, Leece BA, Kovtun Y, Goldmacher VS, Xie H, Steeves RM, Lutz RJ, Zhao R, Wang L, Blättler WA, Chari RV. Semisynthetic maytansine analogues for the targeted treatment of cancer. Journal of medicinal chemistry 2006; 49(14): 4392-4408.

142. Meister A, Anderson ME. Glutathione. Annual review of biochemistry 1983; 52(1): 711-760.

143. Gomez-Roca CA, Boni V, Moreno V, Morris JC, Delord JP, Calvo E, Papadopoulos KP, Rixe O, Cohen P, Tellier A. A phase I study of SAR566658, an anti CA6-antibody drug conjugate (ADC), in patients (Pts) with CA6-positive advanced solid tumors. American society of clinical oncology 2016.

144. Taylor K, Morgan H, Johnson A, Nicholson R. Structure-function analysis of a novel member of the LIV-1 subfamily of zinc transporters, ZIP14. FEBS letters 2005; 579(2): 427-432.

145. El-Tanani MK, Green CD. Interaction between estradiol and growth factors in the regulation of specific gene expression in MCF-7 human breast cancer cells. The journal of steroid biochemistry and molecular biology 1997; 60(5-6): 269-276.

146. Unno J, Satoh K, Hirota M, Kanno A, Hamada S, Ito H, Masamune A, Tsukamoto N, Motoi F, Egawa S, Unno M, Horii A, Shimosegawa T. LIV-1 enhances the aggressive phenotype through the induction of epithelial to mesenchymal transition in human pancreatic carcinoma cells. International journal of oncology 2009; 35(4): 813-821.

147. Grattan BJ, Freake HC. Zinc and cancer: implications for LIV-1 in breast cancer. Nutrients 2012; 4(7): 648675.

148. Taylor K, Morgan H, Johnson A, Nicholson R. Structure-function analysis of a novel member of the LIV-1 subfamily of zinc transporters, ZIP14. FEBS letters 2005 ; 579(2): 427-432 
149. Sussman D, Smith LM, Anderson ME, Duniho S, Hunter JH, Kostner H, Miyamoto JB, Nesterova A, Westendorf L, Van Epps HA, Whiting N, Benjamin DR. SGN-LIV1A: A novel antibody-drug conjugate targeting LIV-1 for the treatment of metastatic breast cancer. Molecular cancer therapeutics 2014; 13(12): 2991-3000.

150. Speers C, Tsimelzon A, Sexton K, Herrick AM, Gutierrez C, Culhane A, Quackenbush J, Hilsenbeck S, Chang J, Brown P. Identification of novel kinase targets for the treatment of estrogen receptor-negative breast cancer. Clinical cancer research 2009; 15(20): 63276340.

151. Maderna A, Doroski M, Subramanyam C, Porte A, Leverett CA, Vetelino BC, Chen Z, Risley H, Parris K, Pandit J, Varghese AH, Shanker S, Song C, Sukuru SC, Farley KA, Wagenaar MM, Shapiro MJ, Musto S, Lam MH, Loganzo F, O'Donnell CJ. Discovery of cytotoxic dolastatin 10 analogues with $\mathrm{N}$-terminal modifications. Journal of medicinal chemistry 2014; 57(24): 10527 10543.

152. Tolcher A, Calvo E, Maitland M, Gibson B, Xuan D, Joh T, Jackson-Fischer A, Damelin M, Barton J, Xin X. 28LBA A phase 1 study of PF-06647020, an antibodydrug conjugate targeting PTK7 in patients with advanced solid tumors. European journal of cancer 2015; 51: S724.

153. Eskelinen EL. Roles of LAMP-1 and LAMP-2 in lysosome biogenesis and autophagy. Molecular aspects of medicine 2006; 27(5-6): 495-502.

154. Saitoh O, Wang W-C, Lotan R, Fukuda M. Differential glycosylation and cell surface expression of lysosomal membrane glycoproteins in sublines of a human colon cancer exhibiting distinct metastatic potentials. Journal of biological chemistry 1992; 267(8): 5700-5711.

155. Baudat Y, Cameron B, Dabdoubi T, Lefebvre A-M, Merino-Trigo A, Thomas C, Pecheux V, Genet B, Calvet L, Blot L. Characterization of a novel maytansinoid-antibody-drug conjugate targeting LAMP1 expressed at the surface of tumor cells. AACR 2016.

156. Calvet L, Lefebvre AM, Nicolazzi C, Blot L, Thomas C, Baudat Y, Cameron B, Garcia-Echeverria C, Mayaux JF, Blanc V. Outstanding preclinical efficacy of a novel maytansinoid-antibody-drug conjugate targeting LAMP1 in patient-derived xenograft solid tumors. AACR 2016.

157.Li DM, Feng YM. Signaling mechanism of cell adhesion molecules in breast cancer metastasis: potential therapeutic targets. Breast cancer research and treatment 2011; 128(1): 7-21.

158. Paredes J, Correia AL, Ribeiro AS, Milanezi F, Cameselle-Teijeiro J, Schmitt FC. Breast carcinomas that co-express E-and P-cadherin are associated with p120-catenin cytoplasmic localisation and poor patient survival. Journal of clinical pathology 2008; 61(7): 856862.

159. Vieira AF, Paredes J. P-cadherin and the journey to cancer metastasis. Molecular cancer 2015; 14: 178.

160. Menezes D, Abrams TJ, Karim C, Tang Y, Ying C, Miller K, Fanton C, Ghoddusi M, Wang Z, Patawaran M. Development and activity of a novel antibody-drug conjugate for the treatment of P-cadherin expressing cancers. AACR 2015.

161. Giaginis C, Tsoukalas N, Bournakis E, Alexandrou P, Kavantzas N, Patsouris E, Theocharis S. Ephrin (Eph) receptor $\mathrm{A} 1, \mathrm{~A} 4, \mathrm{~A} 5$ and $\mathrm{A} 7$ expression in human nonsmall cell lung carcinoma: associations with clinicopathological parameters, tumor proliferative capacity and patients' survival. BMC clinical pathology 2014; 14(1): 8.

162. Liu C, Huang $\mathrm{H}$, Wang $\mathrm{C}$, Kong $\mathrm{Y}$, Zhang $\mathrm{H}$. Involvement of ephrin receptor A4 in pancreatic cancer cell motility and invasion. Oncology letters 2014; 7(6): 2165-2169.

163. Damelin M, Bankovich A, Park A, Aguilar J, Anderson W, Santaguida M, Aujay M, Fong S, Khandke K, Pulito V, Ernstoff E, Escarpe P, Bernstein J, Pysz M, Zhong W, Upeslacis E, Lucas J, Nichols T, Loving K, Foord O, Hampl J, Stull R, Barletta F, Falahatpisheh H, Sapra P, Gerber HP, Dylla SJ. Anti-EFNA4 calicheamicin conjugates effectively target triple-negative breast and ovarian tumor-initiating cells to result in sustained tumor regressions. Clinical cancer research 2015; 21(18): 4165-4173.

164. Hamann PR, Hinman LM, Hollander I, Beyer CF, Lindh D, Holcomb R, Hallett W, Tsou HR, Upeslacis J, Shochat D, Mountain A, Flowers DA, Bernstein I. Gemtuzumab ozogamicin, a potent and selective antiCD33 antibody- calicheamicin conjugate for treatment of acute myeloid leukemia. Bioconjugate chemistry 2002; 13(1): 47-58.

165. Cserni G. Histological type and typing of breast carcinomas and the WHO classification changes over time. Pathologica 2020; 112(1): 25-41. 